\title{
KARAKTER ARSIP SULTAN TERNATE KOLEKSI PERPUSTAKAAN NASIONAL REPUBLIK INDONESIA \\ (The Characteristics of Sultan Ternate's Manuscripts Collection National Library of Indonesia)
}

\author{
Priscila Fitriasih Limbong \\ Fakultas Ilmu Pengetahuan Budaya, Universitas Indonesia \\ Depok-Indonesia \\ Pos-el: Priscila.fitriasih@gmail.com/priscila.fitriasih@ui.ac.id \\ (Diterima:14 Februari 2019; Direvisi: 31 Mei 2019; Disetujui: 31 Mei 2019)
}

\begin{abstract}
National Library of Indonesia has more than 11.000 ancientmanuscripts in their collection. The manuscript collection is devided into two groups, which are bounded book manuscript collection and non-book collection that is stored inside achest. Bounded book manuscript collection is seperated into 17 sub-collections that have quite clear identity and history while chest manuscriptis separated into 37 sub-collections (one of the collections is Sultan Ternate archives) that does not have clear origin and collection characteristics. Related to that, this article will be discussing the characteristics of Sultan Ternate's archives chest manuscript collection. The discussion about this problem had to be done in order to give a clear and comprehensive description about the content and characteristics of the Sultan Ternate's archive collection. The description of the characteristics of Sultan Ternate's archive collection can be beneficialas research data for many studies, especially the one that is related to historical science and codicology.
\end{abstract}

Keywords: National Library of Indonesia; chest manuscript; Sultan Ternate archives; characteristics

\begin{abstract}
Abstrak
Perpustakaan Nasional Republik Indonesia (selanjutnya disebut PNRI) memiliki koleksi naskah kuno sebanyaklebih dari 11.000 naskah. Koleksi naskah tersebut dibagi menjadi dua kelompok besar, yaitu koleksi naskah buku berjilid dan koleksi nonbuku yang tersimpan di dalam peti. Koleksi naskah buku berjilid terbagi atas 17 subkoleksi yang cukup jelas identitas dan sejarahnya, sedangkan naskah peti terbagi atas 37 subkoleksi (antara lain koleksi arsip Sultan Ternate) yang kurang jelas asal muasal dan ciri koleksinya. Sehubungan dengan itu, makalah ini membahas karakteristik koleksi naskah peti arsip Sultan Ternate. Pembahasan masalah ini perlu dilakukan untuk memberikan gambaran yang jelas dan komprehensif tentang isi dan ciri-ciri koleksi arsip Sultan Ternate. Gambaran tentang karakteristik koleksi arsip Sultan Ternate ini dapat dijadikan data penelitian bagi kajian berbagai disiplin ilmu, terutama yang terkait dengan bidang ilmu sejarah dan kodikologi.
\end{abstract}

Kata kunci: PNRI; naskah peti;arsip Sultan Ternate; karakteristik 


\section{PENDAHULUAN}

Koleksi naskah kuno Perpustakaan Nasional Republik Indonesia (selanjutnya disebut PNRI) terdiri atas sepuluh ribuan lebih naskah tulisan tangan, tersusun secara berangsurangsur selama satu setengah abad lebih di bawah pengawasan dan dengan perantaraan sejumlah sarjana bahasa dan kesusastraan Nusantara (Behrend, 1998: xi). Koleksi naskah kuno ini dikumpulkan dengan tujuan menyimpan dan memelihara naskah-naskah peninggalan nenek moyang yang mengandung pengetahuan filosofis, kebudayaan, keagamaan, sejarah, cerita rakyat, mantra, dan lain-lain. Naskah-naskah ini merupakan ungkapan pengalaman dan pikiran para pengarang dan penulisnya yang dapat dijadikan cerminan dan sumber pengetahuan kepada generasi muda penerus bangsa.

Naskah-naskah koleksi PNRI terdiri atas dua kelompok besar, yaitu koleksi buku berjilid dan nonbuku. Koleksi naskah berupa buku berjilid disimpan dalam rak-rak besi dan diurutkan sesuai dengan nama koleksi. Koleksi naskah berupa nonbuku disimpan dalam peti (dulu trommed sekarang kotak karton atau laci kabinet) dan disusun sesuai dengan nomor urut petinya. Naskah koleksi buku berjilid terdiri atas 17 subkoleksi yang cukup jelas identitas dan sejarahnya, sedangkan naskah nonbuku yang disimpan di dalam peti terdiri atas 37 subkoleksi, termasuk beberapa kelompok naskah yang kurang jelas asal muasal maupun ciri koleksinya.

Artikel ini membahas koleksi naskah nonbuku yang disimpan di dalam peti. Naskahnaskah jenis ini pada umumnya berupa arsip dari berbagai daerah dan arsip koleksi berbagai kolektor. Sebagian besar koleksi naskah nonbuku ini tidak jelas asal muasalnya. Selain itu, naskah-naskah nonbuku ini belum ada deskripsi mengenai ciri-ciri fisik dan isi naskah. Hal ini menunjukkan bahwa dokumen ini tidak diolah dengan standar filologi dan menyebabkan pula kurangnya penelitian terhadap naskah peti tersebut.
Sejarah keberadaan koleksi naskah peti di PNRI berawal dari koleksi Bataviaasch Genootschap van Kunsten en Wetenshappen (KBG). Lembaga ini merupakan lembaga ilmiah bentukan Belanda yang mulai melakukan pengadaan naskah-naskah yang terdapat di nusantara pada tahun 1845 . Lembaga ini secara intensif mengumpulkan koleksi kepurbakalaan, etnografi, buku, dan naskah-naskah nusantara. Setelah Indonesia merdeka, KBG berganti nama menjadi Lembaga Kebudajaan Indonesia. Akan tetapi, lama kelamaan identitas lembaga ini mulai luntur ketika gedung dan seluruh koleksinya dijadikan salah satu museum di bawah naungan Kementerian Pendidikan dan Kebudayaan. Selama beberapa dasawarsa koleksi naskah ex-KBG terus berkelompok sebagai salah satu bagian Museum Pusat (Museum Nasional) tetapi kemudian pada tahun 1989, Museum Nasional dipindahkan dan bergabung dengan PNRI. Oleh karena itu, secara otomatis koleksi naskah KBG menjadi koleksi naskah PNRI. Demikian pula dengan koleksi naskah peti arsip Sultan Ternate (Behrend, 1998: xi--xii).

Naskah arsip Sultan Ternate tersebut sampai saat belum memiliki deskripsi fisik maupun isi naskah. Akan tetapi, transliterasi beberapa naskah dari koleksi ini sudah dilakukan oleh Limbong (2018). Dari transliterasi beberapa naskah koleksi naskah arsip Sultan Ternate ini diketahui bahwa naskah-naskah ini memiliki pengetahuan yang berasal dari masa lalu yang penting untuk disosialisakan. Oleh karena itu, pembahasan tentang naskah peti perlu dilakukan mengingat luasnya informasi yang terdapat dalam naskah-naskah peti. Kandungan naskah peti tidak hanya berisi pengetahuan filosofis, kebudayaan, keagamaan, sejarah, bahasa, cerita rakyat dan mantra, tetapi juga mengandung informasi tentang realitas sosial, hukum, dan politik yang menjadi fakta di masa lalu.

Sehubungan dengan hal tersebut, artikel ini membahas karakteristik salah satu koleksi naskah nonbuku yang disimpan di dalam peti. 
Koleksi yang diteliti adalah koleksi arsip Sultan Ternate. Koleksi arsip ini sangat menarik untuk dibahas berhubung pada masanya Ternate memiliki kejayaan di bidang ekonomi dan kemaritiman. Dengan membahas karakteristik koleksi arsip Sultan Ternate ini, pembaca mendapat gambaran tentang isi naskah dan ciri-ciri koleksi arsip Sultan Ternate. Gambaran ini dapat dijadikan data penelitian bagi kajian berbagai disiplin ilmu, terutama yang terkait dengan bidang ilmu sejarah dan kodikologi.

\section{KOLEKSI ARSIP PNRI}

Naskah koleksi arsip PNRI yang disimpan dalam koleksi peti berjumlah 4486 naskah. Jumlah ini hampir separuh dari seluruh koleksi naskah PNRI. Koleksi naskah peti terdiri atas berbagai jenis, baik yang berbentuk buku maupun yang berbentuk nonbuku. Naskah berbentuk buku ditulis di atas kertas, tetapi tidak terjilid. Naskah-naskah ini umumnya berupa catatan ilmiah yang disusun dan dikumpulkan untuk kepentingan pemerintah kolonial Hindia Belanda atau para sarjana yang menjabat sebagai amtenar pemerintah kolonial. Naskah yang berbentuk nonbuku tertulis di dalam tulang, logam, kayu, dan lontar. Jenis naskah ini tidak terlalu banyak jumlahnya dibandingkan naskah berbentuk buku (Behrend, 1998:xxiii).

Koleksi naskah berpeti terdiri atas 37 judul. Judul-judul tersebut, Yaitu sebagai berikut.

Naskah khazanah istimewa

Lontar koleksi kuno Merapi-Merbabu

Lontar aneka kropak Bali dan Jawa

Arsip Buleleng

Naskah pedesaan Lombok

Kropak Asia Tenggara

Naskah Batak

Aneka kropak Jawa Kuno dan Bali

Koleksi lontar Bali

Koleksi lontar Engelenberg

Arsip A.B Cohen Stuart

Aneka ragam Kropak

Aneka transkripsi Bahasa Melayu, Jawa, dan Sunda
Aneka kropak Bali

Naskah rencong

Koleksi peta asal Jepang

Koleksi ilmiah Dr. J.L.A Brandes

Aneka lontar dan bambu

Beberapa naskah silsilah berupa gulungan

Asip van der tuuk

Naskah Tibet, Siam, dan Cina

Arsip catatan K.F. Holle

Konsep Beschrijving der Hss aangetroffen in het nalatenschap Van der Tuuk, susunan J.L.A. Brandes

Bahan leksikografis Van der Tuuk

Arsip J.G.F. Riede (Mix, Mlk, Sul)

Arsip minister van Kolonien

Holle Lijsten

Koleksi naskah Madura

Arsip Sultan Ternate

Varia Sidayu, Surabaya

Koleksi C.M. Playte

Varia berkaitan dengan musik

Rupa-rupa

Koleksi jimat

Varia

Varia KBG

Kamus dan arsip J.A. Wilkens

Koleksi berpeti ini dapat diidentifikasi dari pengodean naskah. Kode naskah diawali dengan nomor peti, nomor subkoleksi, dan nomor urut naskah. Sebagai contoh, naskah 113 1/ 2 , kode pertama (113) menunjukkan koleksi arsip Ternate, kode angka kedua (1) menunjukkan nomor bundel, dan kode ketiga setelah tanda / (2) menunjukkan nomor naskah.

Koleksi arsip ini mengandung pengetahuan yang luas terkait pola pikir, budaya, bahasa, musik, dan lain-lain yang berasal dari berbagai wilayah di Nusantara. Akan tetapi, sangat memprihatinkan, koleksi arsip ini kurang mendapat perhatian dari masyarakat. Padahal, arsip-arsip ini memiliki batas usia layak baca. Usia naskah arsip-arsip ini pada umumnya lebih dari seratus tahun. Usia naskah tersebut dapat dikatakan cukup tua dan berpotensi merusak naskah. Kerusakan naskah yang menjadi media 
penulisan teks arsip menyebabkan kandungan arsip tidak dapat terbaca. Apabila ini terjadi maka kesempatan untuk mentransfer warisan pengetahuan yang berasal dari arsip akan lenyap.

\section{KARAKTERISTIK ARSIP SULTAN TERNATE KOLEKSI PNRI}

Naskah arsip Sultan Ternate yang menjadi koleksi PNRI berjumlah 99 naskah. Jumlah ini dapat dikatakan cukup besar sebagai arsip koleksi. Banyaknya arsip Sultan Ternate ini berkaitan dengan kebesaran Kerajaan Ternate pada masa lalu. Ternate bahkan menjadi penguasa Maluku pada abad XVII (Andaya, 2015:44). Pada masanya, Ternate dikenal sebagai wilayah strategis perdagangan yang disebut bandar jalur sutera. Kepopuleran Ternate sebagai wilayah strategis perdagangan di Nusantara terungkap dalam dalam Kitab Negarakertagama karya Mpu Prapanca (1365). Kitab ini mencatat adanya Maloko yang dapat diartikan sebagai empat kerajaan utama di Maluku Utara atau yang lazim disebut Maluku Kie Raha. Wilayah yang termasuk Maluku Kie Raha itu adalah Ternate, Tidore, Bacan, dan Jailolo (Lapian, 1994:11-22).

Berdasarkan informasi yang terdapat pada kitab tersebut daerah Maluku-termasuk Ternate-pada abad XIV telah menjadi salah satu pusat perhatian bagi perdagangan internasional di jalur pelayaran dan perdagangan Indonesia bagian timur. Sejak awal abad XIV, wilayah ini menjadi arena persaingan perdagangan bahkan pertarungan politik di antara bangsa-bangsa barat, seperti Portugis, Spanyol, Inggris, dan Belanda (Tjandrasasmita, 1997:40).

Konflik Kerajaan Ternate dengan Portugis cukup membebani Kerajaan Ternate. Untuk mengusir Portugis dari Ternate, Sultan Ternate menjalin hubungan diplomasi dengan bangsa lain, yaitu Inggris dan Belanda. Hubungan ini awalnya didasarkan atas asas saling menguntungkan. Ternate membuka hubungan dengan Inggris dan Belanda melalui jalur perdagangan.

Pada tahun 1607, untuk pertama kali Ternate melakukan hubungan dagang dengan VOC. Akan tetapi, pada perjalanan hubungan dagang ini terjadi berbagai gejolak sosial dan politik. Ternate tidak hanya melakukan kontrakkontrak perdagangan dengan VOC (yang kemudian diteruskan oleh Belanda), tetapi juga melakukan kontrak-kontrak politik terkait dengan ancaman terhadap Ternate dari berbagai pihak, baik dari pihak asing maupun dari pihak kerajaan-kerajaan lokal yang dikuasai Ternate. Kontrak-kontrak perdagangan dan politik inilah yang terdokumentasikan di dalam naskah dan menjadi koleksi arsip Sultan Ternate.

\section{Jenis Naskah Arsip Sultan Ternate}

Naskah arsip Sultan Ternate koleksi PNRI tidak memiliki keterangan mengenai isi dan sejarah naskah. Jumlah naskah arsip Sultan Ternate koleksi PNRI berjumlah 99 naskah yang berasal dari masa kolonial Belanda. Naskah arsip tersebut terdiri atas beberapa jenis, yaitu sebagai berikut.

1. Arsip kontrak dan peraturan (54 naskah),

2. Buku cerita (13 naskah),

3. Daftar-daftar (7 naskah),

4. Proses verbaal (6 naskah),

5. Plakat (1 naskah),

6. Buku hukuman (10 naskah),

7. Buku peringatan (7naskah),

8. Buku keluhan (1 naskah).

Jenis naskah arsip Sultan Ternate yang dominan adalah naskah arsip kontrak dan perjanjian. Oleh karena itu, pembahasan karakteristik arsip Sultan Ternate ini dibatasi pada arsip berupa kontrak dan perjanjian. Arsip ini terdiri atas berbagai macam, antara lain kontrak dan perjanjian yang berkaitan dengan masalah politik, hukum, dan ekonomi. Banyaknya naskah arsip berupa kontrak dan perjanjian ini memperlihatkan bahwa pada masa lalu Ternate telah melakukan hubungan diplomasi dengan Belanda yang cukup intensif dan meneguhkan hubungan tersebut secara formal melalui perjanjian-perjanjian yang tertulis dan terdokumentasikan secara legal formal. 


\section{Ciri-Ciri Naskah Arsip Sultan Ternate}

Seperti yang sudah disinggung di atas, usia naskah-naskah arsip Sultan Ternate sudah lebih dari seratus tahun. Teks naskah-naskah ini pada umumnya masih dapat dibaca, tetapi kondisi fisiknya saat ini sudah mulai mengkhawatirkan. Pada umumnya, fisik naskahnya sudah rusak, tulisannya kabur, dan kertasnya rapuh. Kondisi cuaca dan udara tempat penyimpanan naskah yang tidak layak berkontribusi memperburuk kondisi naskah. Di bawah ini merupakan tujuh sampel naskah yang dapat memberikan gambaran umum tentang kondisi naskah arsiparsip Sultan Ternate.

\section{Naskah berkode 113 8/1}

Naskah berkode 113 8/1 ini merupakan naskah yang ditulis dengan aksara Jawi dan beberapa halaman ditulis dengan huruf Latin. Tulisan dalam naskah UUT ditulis dengan huruf Jawi yang dicetak dengan menggunakan tinta hitam pekat. Kondisi naskah masih cukup baik, tidak berlubang, dan dapat dibaca dengan jelas.

Kertas yang digunakan dalam naskah ini adalah kertas Eropa berwarna putih kecokelatcokelatan. Naskah ditulis di kertas folio. Halaman 1 dan 2 ditulis pada bagian muka halaman dari kanan ke kiri, bagian belakang pada kertas ini merupakan halaman kosong.

Teknik penjilidan naskah ini menggunakan teknik jelujur. Tiap halaman dijahit dengan benang yang dijahit jelujur, kemudian tiap jahitan disatukan menjadi satu kesatuan naskah yang utuh. Namun, karena usia naskah yang semakin tua, kondisi benang terlepas sehingga naskah menjadi lembaran-lembaran yang terpisah. Hal ini dapat dilihat pada halaman 9. Pada halaman ini ditemukan sisa benang jahitan.

Halaman sampul naskah UUT berbahan kertas yang sama dengan halaman isi naskah, yaitu kertas Eropa berwarna putih kecokelatcokelatan. Cap kertas pada halaman sampul UUT bertuliskan "Landsdrukkerij Batavia," Sementara itu, cap kertas pada halaman naskah bergambarkan seekor singa bermahkota yang sedang menghadap ke kiri atas sambil memperhatikan pedang pendek yang dipegang di tangan kirinya. Gambar tersebut berada dalam sebuah lingkaran yang di atasnya terdapat mahkota berpangkal salib. Seekor singa tersebut berada dalam lingkaran bertuliskan "Pro Patria Eendragt Maaktmagt." Berdasarkan informasi yang terdapat pada katalog watermark yang disusun oleh Churchill (1935:37) cap kertas ini diproduksi oleh pabrik kertas van Der Ley pada tahun 1808 .

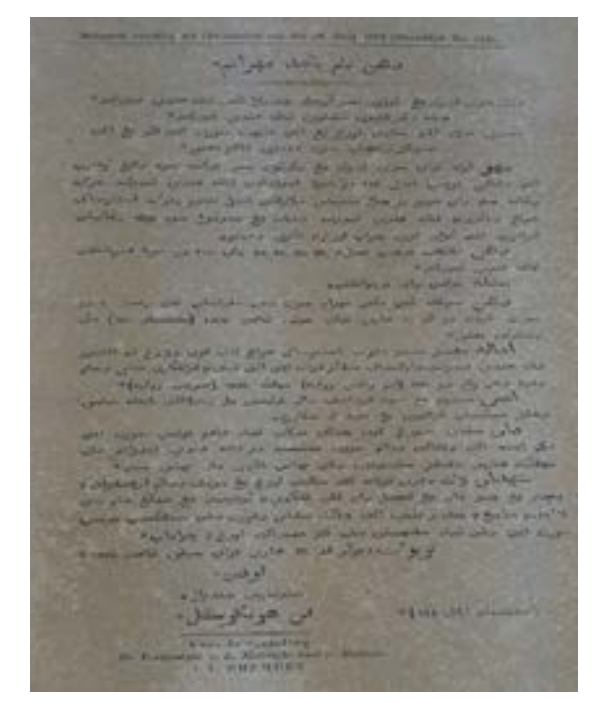

Gambar 1: Kondisi dan aksara naskah

\section{Naskah berkode113 8/3a}

Naskah ini ditulis di atas kertas berukuran 34.5 X $21.5 \mathrm{~cm}$. Kertas yang digunakan merupakan kertas folio tipis yang tidak memiliki watermark maupun countermark. Jumlah baris per halaman teks teks rata-rata 27 baris per halaman. Kondisi naskah ini sudah mulai rusak. Kuras pada naskah ini mulai lepas. Pinggiran kertas mulai gerepes, kertas sudah rapuh, kering, dan patah. Akan tetapi, warna tinta masih sangat jelas. Tulisan pada naskah ini pun sangat jelas karena ditulis dengan ukuran huruf yang besar dan tulisan yang rapih.

Teks yang terdapat dalam naskah ini dibagi atas dua blok, teks pada blok sebelah kiri ditulis dengan menggunakan huruf Jawi dan 
teks pada blok sebelah kanan ditulis dengan huruf Latin berbahasa Belanda.

Pada naskah ini terdapat cap Kerajaan Ternate. Kondisi cap tersebut sudah pudar dan bagian tengah kertas pada cap tersebut patah. Kondisi cap Residen Ternate juga sudah pudar tetapi tidak terlihat ada bagian kertas yang patah.

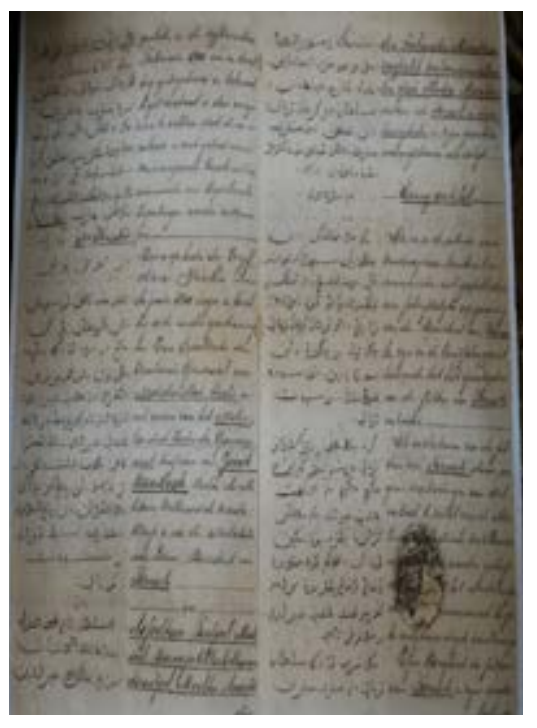

Gambar 2. Kondisi dan cap naskah

\section{Naskah Berkode 113 8/4}

Naskah ini menggunakan kertas folio tebal yang tidak memiliki watermark tetapi terdapat countermark yang kelihatan jelas. Jumlah baris per halaman teks teks rata-rata 26 baris per halaman. Kondisi naskah ini sudah mulai rusak. Kertas sudah berwarna kecokelatan dan terlepas dari kurasnya. Pinggiran kertas mulai gerepes, kertas sudah rapuh, kering, dan patah. Akan tetapi, warna tinta masih sangat jelas. Sebagian tinta dalam kondisi memakan kertas. Tulisan pada naskah ini pun sangat jelas karena ditulis dengan ukuran huruf yang besar dan tulisan yang rapih.

Teks yang terdapat dalam naskah ini dibagi atas dua blok, teks pada blok sebelah kiri ditulis dengan menggunakan huruf Jawi dan teks pada blok sebelah kanan ditulis dengan huruf Latin berbahasa Belanda.

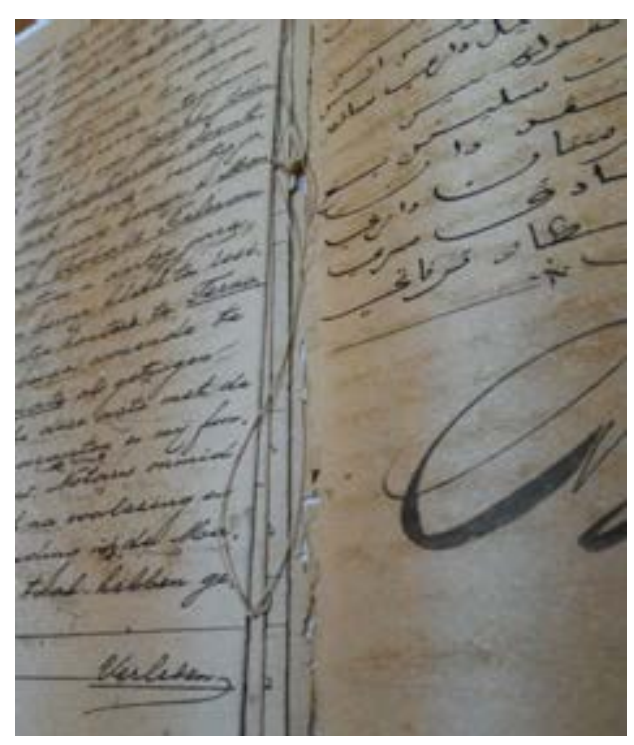

Gambar 3. Format dan bahasa naskah

\section{Naskah berkode 113 8/ 16}

Naskah berkode 113 8/16 ini merupakan naskah berhuruf Latin dengan bahasa Melayu pada kolom bagian kiri dan bahasa Belanda pada kolom bagian kanan. Di dalam naskah ini terdapat dua bundel teks yang isinya sama. Bundel teks yang pertama ditulis dengan cara ditik menggunakan tinta hitam, sedangkan bundel teks yang kedua ditik dengan menggunakan tinta berwarna biru. Kondisi naskah masih cukup baik, tidak berlubang, dan dapat dibaca dengan jelas.

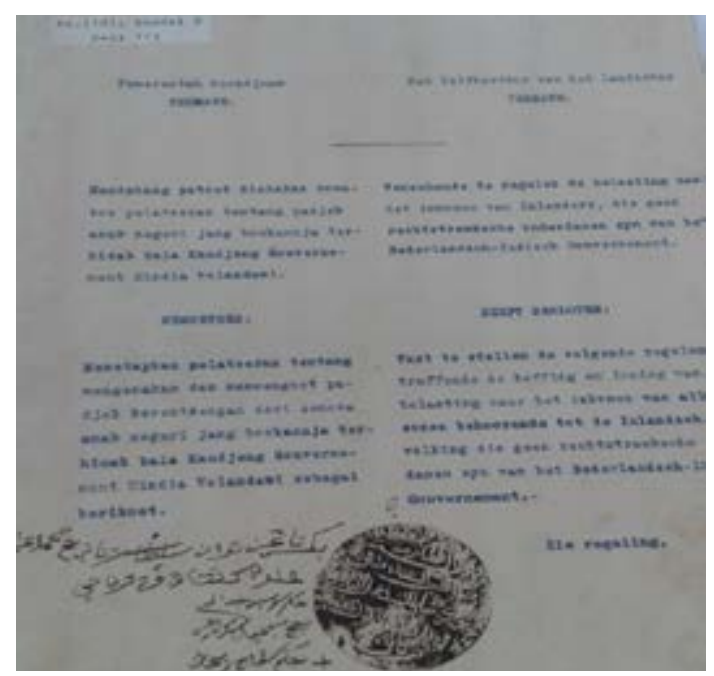

Gambar 4. Huruf yang digunakan dalam naskah 
Naskah ini memiliki kolofon. Kolofon naskah menjelaskan bahwa naskah ini ditulis pada tanggal 1 Januari 1912. Pejabat yang melegalisasikan surat keputusan ini adalah Sultan Ternate Haji Muhamad Utsman, Alwi Kapten Laut, Hakim Abdullah, dan Sekretaris Haji Utsman. Di samping kolofon terdapat cap yang bertuliskan, "Dilalatul mukarom/ shahib assalathin/ yuwarits alla assyadili andasi/fi buldan al-Maluku/Ternate."

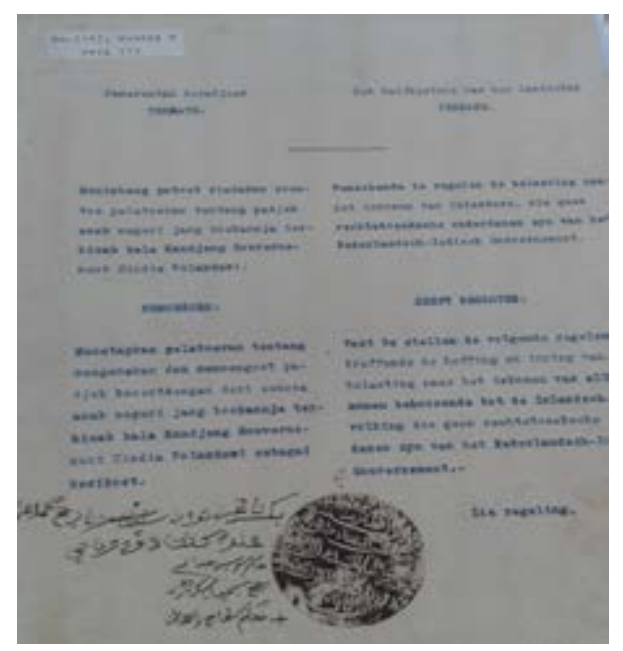

Gambar 5. Kolofon naskah yang berisi cap dan nama pejabat yang melegalisasikan surat keputusan

\section{Naskah berkode 113 8/20}

Naskah berkode $1138 / 20$ a dan b ini menggunakan huruf Jawi dan huruf Latin. Kondisi naskah cukup baik walaupun sampul naskah memperlihatkan kerusakan. Naskah ditulis di atas kertas folio berukuran $35 \mathrm{~cm} \mathrm{X}$ $19 \mathrm{~cm}$. Naskah ini terdiri atas 2 bundel naskah, yaitu naskah bernomor 113 8/20a dan naskah bernomor $1138 / 20$ b. Setiap lembar naskah terdiri atas 2 kolom. Kolom sebelah kiri ditulis menggunakan huruf Jawi sedangkan kolom sebelah kanan ditulis dengan huruf Latin berbahasa Belanda.

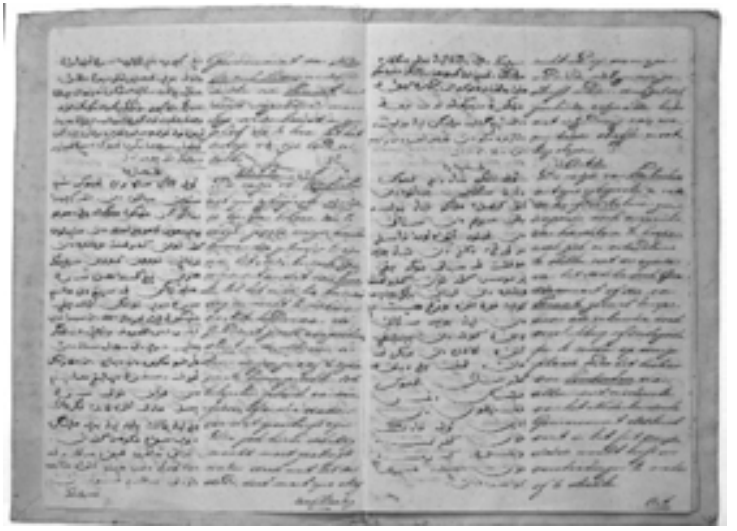

Gambar 6. Aksara dan bahasa naskah

Bahan dari naskah ini adalah kertas berwarna putih kecokelatan. Tidak terdapat watermark pada kertas naskah ini. Pada halaman 18, terdapat cap kerajaan Belanda tanpa tinta (cap timbul) sebagai bentuk legalisasi yang digunakan untuk dokumen resmi pemerintahan. Cap tersebut bertulisakan, "Gouverneur Generaal Van Nederlandsch Indie,"

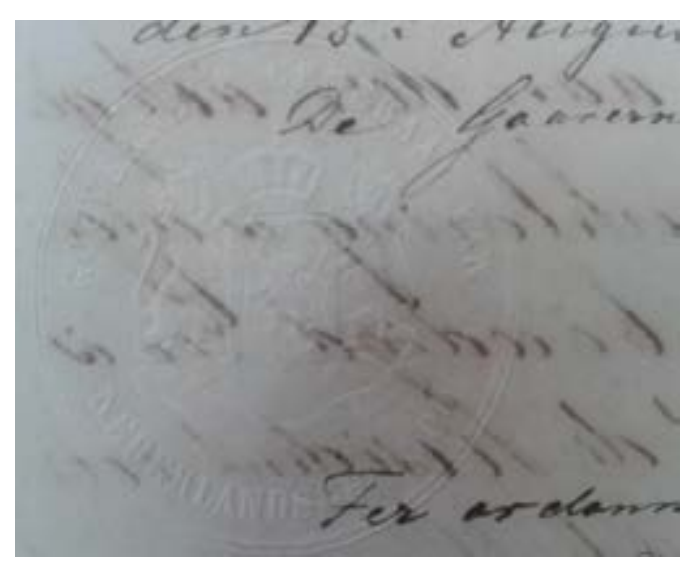

Gambar 7. Cap timbul kerajaan Belanda

Pada naskah ini terdapat dua buah kolofon. Kolofon pertama terdapat di halaman 14 yang bertuliskan "Ternate pada satu hari bulan sya'ban 1351" dengan huruf Arab, sedangkan kolofon kedua terdapat pada halaman 23 yang bertuliskan "Ternate den 28 Mei 1884" dengan huruf Latin. 


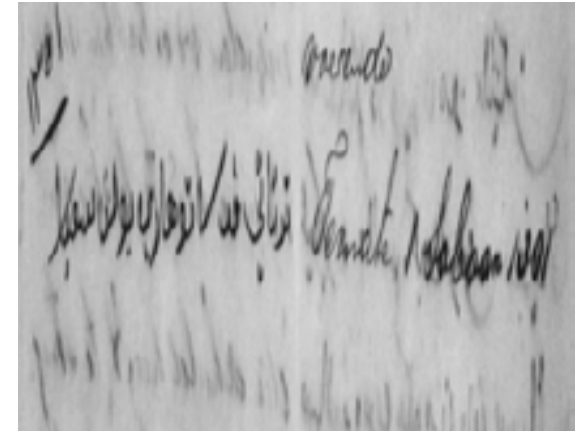

Gambar 8. Kolofon naskah

\section{Naskah berkode 113 8/33}

Naskah UUTberkode 113 8/33 merupakan naskah berhuruf Jawi. Tulisan dalam naskah UUT menggunakan tinta hitam yang mulai berubah warna menjadi cokelat. Naskah UUT dibaca dengan menggunakan sistem baca dari kanan ke kiri, seperti membaca tulisan Arab. Kondisi naskah sudah rapuh. Terdapat banyak lubang pada setiap halamannya, tinta tulisan berbayang dan keadaan kertas yang sudah lapuk sehingga naskah ini sulit untuk dibaca.

Kertas yang digunakan dalam naskah ini, yaitu kertas eropa berwarna putih kecokelatcokelatan. Teknik penjilidan menggunakan teknik jelujur. Tiap halaman naskah ini dijahit dengan dua jelujur kemudian jelujur pada tiap halaman tersebut disatukan dengan satu halaman naskah sehingga membentuk kuras.

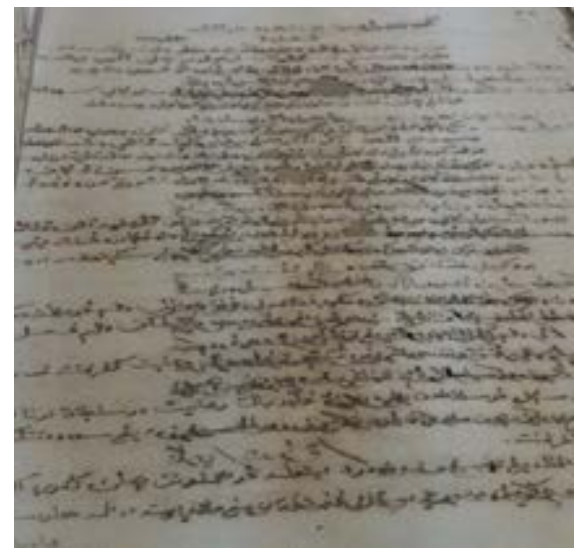

Gambar 9. Kondisi naskah

Halaman sampul naskah UUT berbahan kertas yang lebih tebal dari isi naskah. Kemungkinan kertas yang digunakan pada naskah ini adalah kertas Eropa. Namun, penulis tidak dapat mengidentifikasi jenis kertas dan tahun pembuatan kertas karena sulitnya menemukan cap kertas pada naskah yang disebabkan kondisi naskah yang sudah rapuh.

\section{Naskah berkode 113 8/45}

Naskah ini berukuran folio, menggunakan huruf Jawi, terdiri atas 4 halaman, dan berisi perjanjian antara Raja Tambuku dengan Gubernur Jenderal Hindia Belanda dan Sultan Ternate. Naskah ini ditulis pada tahun 1884 . Naskah ini mengandung isi yang sama dengan naskah 113 8/20. Akan tetapi, pada naskah ini tidak terdapat surat tentukan dan pasal tambahan seperti yang terdapat pada naskah 113 8/20.

Naskah ini tidak memiliki halaman sampul baik di depan maupun di belakang. Hanya terdapat satu halaman pelindung di depan naskah dan tiga halaman pelindung di belakang naskah. Naskah tersebut ditulis menggunakan kertas Eropa berukuran $34.3 \mathrm{~cm}$ X $21.5 \mathrm{~cm}$. Ciri kertas Eropa tersebut terlihat melalui cap kertas (watermark) yang tercetak besar memenuhi bagian tengah halaman. Watermark tersebut berbentuk lingkaran bertuliskan Concordia Resparvae Rescunt yang di dalamnya terdapat gambar singa bermahkota. Berdasarkan informasi yang terdapat pada katalog watermark yang disusun oleh Churchill (1935:127) cap kertas ini diproduksi oleh perusahaan cap kertas van Der Ley pada tahun antara tahun 1698--1815.

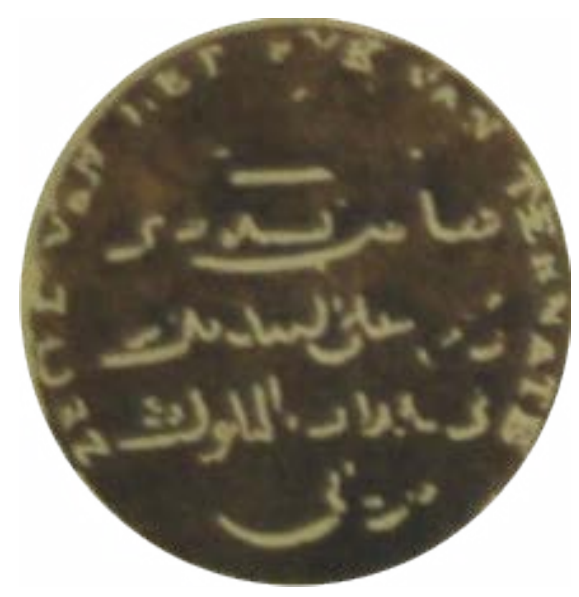

Gambar 10.Watermark pada naskah 
Kondisi naskah ini secara umumcukup bagus, namun bagian ujung kertasnya sudah mulai rapuh. Naskah tersebut ditulis menggunakan garis bantuan pensil horizontal sepanjang $18 \mathrm{~cm}$. Dalam halaman pertama dan kedua, terdapat 30 garis horizontal untuk membantu penulis agar naskah tertulis secara rapi.Naskah ini ditulis menggunakan huruf Arab berbahasa Melayu. Tidak ada informasi mengenai siapa yang menulis maupun menyalin naskah. Akan tetapi, halaman pertama undangundang tersebut terdapat dua cap kerajaan berwarna hitam dan merah, sedangkan di bagian akhir terdapat cap berwarna hitam.

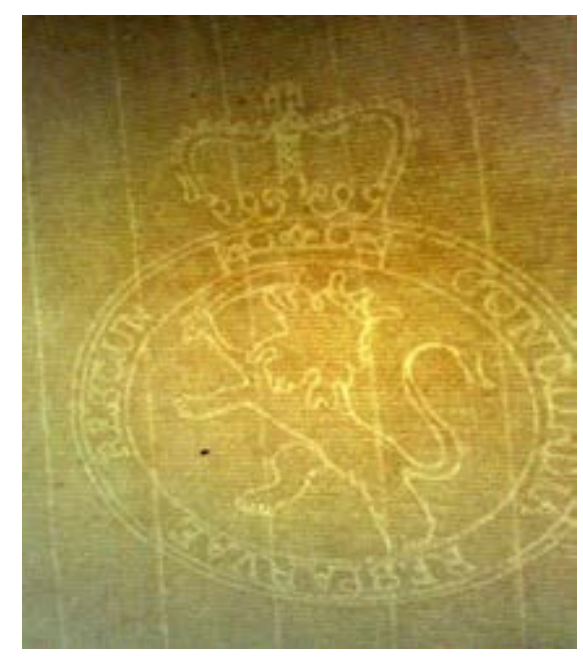

Gambar 11. Cap Kerajaan Ternate yang terdapat pada halaman 1

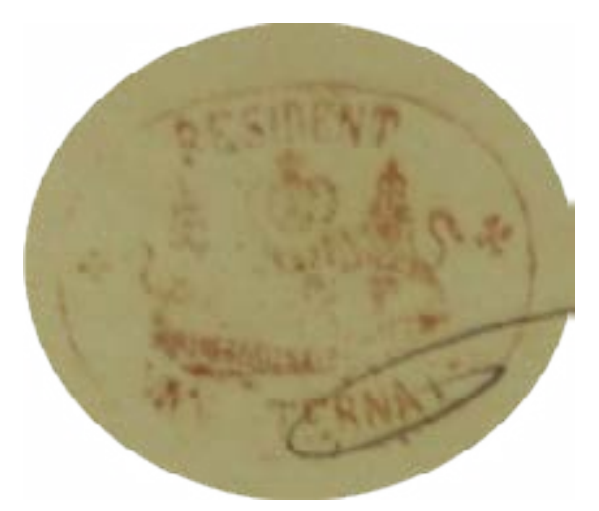

Gambar 12. Cap Kerajaan Ternate yang terdapat pada halaman 1

Naskah Undang Undang Ternate berkode 113 8/45 tidak memiliki sampul.
Naskah tersebut hanya diberi penutup kertas karton putih tebal dari Perpustakaan Nasional Republik Indonesia. Naskah tersebut dijahit dengan rapih sehingga lembar-lembar kertas membentuk satu kesatuan naskah. Benang jahitan yang mengikat lembar-lembar naskah tersebut terlihat masih sangat kuat.

Dari uraian di atas dapat disimpulkan ciri-ciri fisik naskah arsip Sultan Ternate. Pada umumnya bahan naskah arsip Sultan Ternate adalah kertas. Kertas yang digunakan adalah kertas Eropa yang sebagian besar memiliki watermark yang umumnya produksi Propratria. Watermark pada kertas ini memperlihatkan tahun diproduksinya naskah tersebut. Berdasarkan watermark dan data yang terdapat di dalam naskah, pada umumnya naskah-naskah arsip Ternate di PNRI ditulis pada abad XIX. Naskah yang tertua ditulis pada tahun 1800 dan naskah yang termuda ditulis pada tahun 1906 .

Sementara itu, bahasa yang digunakan dalam naskah arsip Sultan Ternate adalah bahasa Belanda, Inggris, Melayu, dan pada umumnya arsip Ternate ditulis dalam dua kolom. Salah satu kolom ditulis menggunakan bahasa Melayu dan kolom lainnya ditulis dalam bahasa asing (dalam hal ini yang mendominasi adalah bahasa Belanda).

Aksara Latin, Jawi (Arab Melayu), dan aksara Arab merupakan aksara yang digunakan dalam penulisan arsip Ternate. Aksara latin digunakan untuk kepentingan pembaca non Melayu, aksara Jawi digunakan untuk kepentingan pembaca pribumi, dan aksara Arab digunakan untuk menulis kutipan-kutipan ayat Alquran, doa-doa, dan istilah-istilah tertentu yang sudah menjadi bagian dari khazanah kosakata Ternate.

Arsip-arsip Sultan Ternate pada umumnya merupakan surat kontrak atau perjanjian yang dibuat oleh pihak Belanda, pihak Ternate, dan pihak kerajaan lokal yang berada di bawah kekuasaan Ternate. Arsip-arsip ini merupakan dokumen resmi pemerintahan. Oleh karena itu, naskah arsip-arsip berjenis kontrak atau surat perjanjian ini selalu diikuti dengan stempel 
atau cap kerajaan. Posisi stempel atau cap memperlihatkan kedudukan setiap pihak yang tersebut di dalam arsip (Gallop,1992:13).

\section{Kandungan Naskah Arsip Sultan Ternate}

Naskah arsip-arsip Sultan Ternate pada umumnya berisi kontrak atau perjanjian terkait masalah politik, hukum, ekonomi, dan kependudukan. Jenis naskah arsip yang mendominasi adalah naskah arsip perjanjian yang berfungsi menjadi undang-undang yang disepakati bersama. Naskah arsip berisi undang-undang ini merupakan koleksi naskah peti PNRI yang terdapat pada katalog naskah PNRI yang terbaru, yang dibuat pada tahun 1998 (Limbong, 2018:131). Naskah arsip Sultan Ternate yang umumnya berupa surat kontrak atau surat perjanjian ini memiliki pola pasal kontrak atau perjanjian sebagai berikut.

1. Pasal-pasal dan sumpahan yang dilakukan oleh petinggi kerajaan (naskah dengan kode 113 8/ 1, 113 8/ 20, 113 8/45).

2. Arsip-arsip ini secara keseluruhan berisi tentang pengakuan Kesultanan Ternate terhadap kekuasaan Belanda. Pengakuan Paduka Sri Sultan Ternate atas kedaulatan pihak Belanda. Pengakuan kedaulatan ini dibuktikan dengan setia pada pemerintah kolonial dan tunduk atas perintahnya (naskah dengan kode $1138 / 1,1138 / 3,113$ 8/4, $1138 / 16,113$ 8/ 20, 113 8/45).

3. Pemerintahan Ternate yang membawahi kerajaan-kerajaan lokal dan tanah-tanah yang ada dalam perjanjian sebelumnya dikembalikan kepada pihak Belanda (naskah dengan kode $1138 / 1,1138 / 3$, 113 8/4).

4. Pernyataan bahwa musuh-musuh dan teman-teman dari pihak kolonial merupakan teman dan musuh dari Kesultanan Ternate juga (naskah dengan kode 113 8/ 1, 113 8/ 20, 113 8/45).

5. Pasal tentang bantuan yang akan diberikan oleh kedua pihak. Pihak
Kesultanan Ternate berjanji akan membantu pihak kolonial dengan perkakas, senjata, dan tenaga manusia dalam berperang melawan musuh, sebaliknya pihak koloni akan membantu pihak Kesultanan Ternate apabila ada kerusuhan yang terjadi dari dalam maupun dari luar kerajaan (naskah dengan kode 113 8/3, 113 8/20 dan 113 8/45).

6. Perubahan bentuk hukuman kepada petinggi-petinggi kerajaan yang memberikan perlindungan kepada orang yang berkhianat kepada pihak kolonial (naskah dengan kode 113 8/ 20 dan 113 8/45).

7. Orang kulit putih dan hitam yangberasal dari luar dan datang ke daerah Kesultanan Ternate harus segera diserahkan kepada pihak kolonial (naskah dengan kode 113 8/ 1,113 8/4, 113 8/ 20, 113 8/45).

8. Perjanjian untuk tidak membuat perjanjian persahabatan dengan pihak lain. Pihak koloni melarang pihak Kesultanan Ternate membuat perjanjian dengan orang kulit putih lainnya (naskah dengan kode 113 8/1, 113 8/3 113 8/ 20, 113 8/45).

9. Peraturan pergaulan rakyat Kesultanan Ternate. Prins-prins, raja-raja bahkan rakyat biasa tidak boleh berkirim surat maupun berbicara dengan orang kulit putih lainnya dan apabila melanggar mereka akan diberi hukuman (naskah dengan kode 113 8/ 1, 113 8/ 20, 113 8/45).

10. Apabila ada kerusuhan yang terjadi di Kesultanan Ternate maka pihak Paduka Sri Sultan secepatnya memerintah dan menyetujui orang-orang yang ada di pemerintahan Ternate untuk membereskannya (naskah dengan kode $1138 / 1,1138 / 3,1138 / 4,1138 / 20$, 113 8/45).

11. Pemilihan pejabat Kesultanan Ternate harus melalui sepengetahuan dan 
persetujuan dari pemerintah Belanda (naskah dengan kode $1138 / 1,1138 / 20$, 113 8/45).

12. Wewenang memberikan putusan hukuman. Paduka Sri Sultan Ternate tidak bisa memberikan hukuman kepada orang yang bersalah tanpa izin dari pemerintahan di Ternate (naskah dengan kode $1138 / 1,1138 / 3,1138 / 4,1138 / 20$, $1138 / 45)$.

13. Pemberian hukuman berat dari Paduka Sri Sultan Ternate harus atas juru hukum yang dipercaya dan telah disetujui oleh pemerintahan di Ternate (naskah dengan kode 113 8/ 1,113 8/16, 113 8/ 20, 113 8/45).

14. Proses memanen tanaman cengkih dan pala harus atas penunjukkan langsung Paduka Sri Sultan Ternate kepada orang yang ditugaskan memanen tanaman cengkih dan pala dan harus ada petinggi negara yang memantaunya. Pemberian hukuman akan diberikan kepada pihak yang melanggar (naskah dengan kode 113 8/ 1, 113 8/3, 113 8/4, 113 8/16).

15. Pembelian perkakas rumah, kayukayu ditanggung oleh Paduka Sri Sultan Ternate. Pembelian perkakas rumah tangga dan kayu ini diminta dari upeti yang didapat oleh pihak kolonial (naskah dengan kode 113 8/ 1, 113 8/3, 113 8/4, $1138 / 16,1138 / 20,1138 / 45)$.

16. Pembangunan dan penghancuran benteng atau kota-kota di tanah Maluku harus atas izin pemerintahan di Ternate. Perdagangan di perairan Maluku (naskah dengan kode $1138 / 1,1138 / 3,1138 / 4$, $1138 / 16,1138 / 20,1138 / 45)$.

17. Jalur perdagangan yang melewati Ambon, Banda, dan sekitarnya terbuka untuk Kerajaan Ternate (naskah dengan kode 113 8/ 1, 113 8/3, 113 8/4, 113 8/ 20, $1138 / 45)$.

18. Pembayaran upeti dilakukan kepada Paduka Sri Sultan Ternate dan petinggipetinggi yang ada di Kesultanan Ternate kepada pihak Belanda. Pembayaran ini dilakukan dalam periode tiga bulan sekali (naskah dengan kode 113 8/ 1, 113 8/ 20, 113 8/45).

19. Kerajaan-kerajaan lokal di bawah kekuasaan Ternate menyatakan akan melarang kegiatan menyabung ayam, minum tuak, mengisap madat, dan kegiatan yang tidak pantas. Jika kegiatankegiatan itu dilakukan maka akan dikenai hukuman. Hukuman itu bukan berupa hukuman pasung atau hukuman keras, seperti hukum qisas, rajam, atau zaladah, melainkan hukuman denda (naskah dengan kode 113 8/ 20 dan 113 8/45).

20. Pihak kerajaan-kerajaan lokal akan memberikan upeti setiap tahun kepada pihak Ternate (naskah dengan kode 113 8/ 1, 113 8/16, 113 8/ 20, 113 8/45).

21. Pemerintah Kolonial Belanda melarang pemberian upeti berupa budak dan sistem perbudakan (naskah dengan kode 113 8/ 1, 113 8/ 20, 113 8/45).

22. Bagian penutup surat diisi dengan sumpahan para petinggi dari Kesultanan Ternate, yaitu Paduka Sri Sultan Ternate, menteri-menteri, dan prinsprins. Isi sumpahan ketiganya adalah mengakui kedaulatan dari pemerintahan Belanda yang memerintah di Kesultanan Ternate, bersumpah akan patuh terhadap perjanjian yang sudah dibuat dan telah diperbaharui, dan bersumpah akan selalu membantu pemerintah kolonial apabila mendapat kesulitan (naskah dengan kode 113 8/ 1, 113 8/ 20, 113 8/45).

Kandungan isi naskah arsip-arsip Sultan Ternate yang telah diuraikan di atas sebagian besar merupakan respons adanya kebijakan etis yang diterapkan Belanda. Menjelang akhir abad XIX, Belanda menerapkan kebijakan etis yang menghapus peraturan yang sewenangwenang tentang penggunaan candu dan sistem perbudakan (Ricklefts, 2008). Pemerintah 
Belanda melarang perbudakan dengan peraturan yang termuat dalam Ind Stb No.40 dan 47.

Larangan ini sebagai implementasi pasal 115 regering sreglement 1854 yang memerintahkan selambat-lambatnya pada tanggal 1 Januari 1860 perbudakan di seluruh Hindia Belanda ditiadakan (Wignyosoebroto, 2014:81). Kebijakan etis Belanda ini sudah mulai diterapkan pada tahun 1884 dan tertera dalam beberapa naskah arsip-arsip Sultan Ternate. Sebelum adanya intervensi Belanda, Pemerintahan Ternate memiliki bentuk hukum yang mengacu pada hukum Islam. Hal ini didasari oleh kepercayaan dan keyakinan masyarakat kerajaan-kerjaaan lokal di bawah kekuasaan Ternate terhadap Islam. Pemerintahan Ternate mengadopsi hukum Islam dalam mengatur kehidupan masyarakat. Akan tetapi, Belanda menghilangkan bentuk hukum Islam tersebut karena dianggap berpotensi merugikan Belanda.

Isi naskah arsip-arsip Sultan Ternate pada umumnya memperlihatkan dominasi kekuasaan Belanda terhadap Ternate dan kerajaan-kerajaan lokal yang dikuasai Ternate. Dominasi ini terlihat pada pasal-pasal yang tercantum pada naskah arsip-arsip Ternate di atas. Selain itu, naskah arsip-arsip ini juga memperlihatkan sisi humanis Belanda terhadap Ternate yang terlihat pada pelarangan madat, nyandu, dan praktik perbudakan. Sisi humanis itu tidak didasarkan pada kesadaran diri Belanda, tetapi karena adanya tuntutan dari pemimpin-pemimpin politik dan masyarakat global yang merespon bentuk kolonialisme di berbagai negara.

\section{PENUTUP}

Koleksi naskah arsip Sultan Ternate memiliki karakter yang memperlihatkan ciriciri fisik dan isi naskah arsip yang khas. Ciriciri fisik naskah arsip yang mulai rusak ini memperlihatkan kondisi naskah terkait usia naskah yang berasal dari abad XIX. Gambaran kondisi fisik naskah yang mulai rusak ini menimbulkan keprihatinan terhadap potensi hilangnya kandungan naskah. Hilangnya informasi dan pengetahuan yang ada di dalam naskah berarti hilangnya kesempatan mempelajari dan mengkaji naskah arsip. Padahal, kandungan arsip dapat digunakan untuk mengatasi masalah-masalah yang relevan dengan isi arsip atau kebutuhan untuk memaknai kehidupan, sistem politik, hukum, dan ekonomi yang terkandung di dalamnya. Adapun, isi arsip-arsip Sultan Ternate ini memperlihatkan pola yang sama yang didahului dengan pengakuan adanya kekuasaan Belanda dan ditutup dengan sumpah setia kepada pihak Belanda dan Ternate.

Karakteristik arsip-arsip Ternate secara fisik ataupun isi dapat dimanfaatkan sebagai objek penelitianlintas ilmu. Karakteristik naskah arsip-arsip ini juga berkontribusi membuka wawasan pembaca tentang berbagai isue. Selain itu, pengetahuan tentang karakteristik naskah, turut memberikan pemahaman bahwa naskah-naskah klasik masih relevan dengan isu yang terjadi pada masa kini terkait dengan isu politik, sosial, dan hukum.

\section{DAFTAR PUSTAKA}

Andaya, Leonard Y. (2015). Dunia Maluku. Yogyakarta: Penerbit Ombak.

Behrend, Tim. 1998. Katalog Induk Naskahnaskah Nusantara Perpustakaan Nasional Republik Indonesia. Jakarta: Yayasan Obor Indonesia dan Ecole Francaise D' Extreme Orient.

Churchill, W.A. (1935). Watermark in Papaer in Holland, England, France, ETS, in The XVII and XVIII Centures and Their Interconnection. Amsterdam: Menno Hertzberger \& Co.

Gallop, Annabel Teh. (1991). Surat Emas Budaya Tulis di Indonesia. London: British Library.

Jusuf, Jumsari., dkk. (1980). Katalog Naskah Maluku. Jakarta: Departemen Pendidikan dan Kebudayaan Direktorat Jenderal Kebudayaan Museum Nasional. 
Lapian, A.B. (1994). "Bacan and The Early History of Maluku" dalam L.E Visser (ed) Halmahera and Beyond. Social Science Research in The Moluccas. Leiden: KITLV Press.

Limbong, Priscila Fitriasih. (2018). Transliterasi Naskah Arsip-Arsip Sultan Ternate Koleksi Perpustakaan Nasional Republik Indonesia. Jakarta:Perpustakaan Nasional Republik Indonesia.

Limbong, Priscila Fitriasih. (2018). 'The Relationship between Structure and Power in Nineteenth Century of UndangUndang Ternate" Selected Topics on Archaelogy, History and Culture in The Malay World. Mohd

Rohaziat Abdul Wahab, Ros Mahwati Ahmad Zakaria,
Hadrawi, Ramli. Ed. Singapore: Springer.

Putten, J. v. (2017), On the edge of a tradition: Some prolegomena to Paratext in Malay rental Manuscripts. Indonesia and The Malay World, 45 (132), 179-199.

Ricklefts (2008), Sejarah Indonesia Modern 1200-2005. Jakarta: Serambi.

Tjandrasasmita, Uka. (1997), "Struktur Masyarakat Kota Pelabuhan Ternate Abad XIV-XVII" dalam Ternate di Bandar Jalur Sutera. Jakarta: Departemen Pendidikan dan Kebudayaan RI.

Wignjosoebroto, Soetandyo. (2014) Dari Hukum ke Hukum Nasional: Suatu Kajian tentang Dinamika Sosial-Politik dalam Perkembangan Hukum Selama Satu Setengah Abad di Indoenesia (1840 - 1990). Jakarta: PT Raja Grafindo Persada. 